\title{
PENYESUAIAN BUDAYA DALAM PERKAWINAN
}

\author{
Sri Hidayati ${ }^{1}$
}

\begin{abstract}
The meaning of marriage is not just a meeting of two individuals, but also a cultural encounter behind both. To achieve success marital couples should make the process of cultural adjustment. This study aimed to describe the profile of cultural adjustment in the marital from aspects of thoughts, feelings, and actions of the husband or wife to her lover. The method used is descriptive method with quantitative approach. These samples included 50 people. Data were collected using a questionnaire designed based on the ordinal scale. Data analysis using Pearson Product Moment correlation. The results showed cultural adjustment in marriage at all respondents have achieved well adjustment. This conclusion is supported by data that measured three aspects of the figure level adjustment respondents as follows: 61 percent thought aspect, the aspect of feeling 84 percent, and 71 percent of the action aspects.
\end{abstract}

Keywords: Cultural Adjustment, Marital Adjustment, Ethnicity.

JOMSIGN: Journal of Multicultural Studies in Guidance and Counseling

Website : http://ejournal.upi.edu/index.php/JOMSIGN

Permalink: http://ejournal.upi.edu/index.php/JOMSIGN/article/view/6053

How to cite (APA): Hidayati, S. (2017). Penyesuaian budaya dalam perkawinan. JOMSIGN: Journal of Multicultural Studies in Guidance and Counseling, 1(1), 83-98.

This is an open access article distributed under the terms of the Creative Commons Attribution 4.0 International License, which permits unrestricted use, distribution, and reproduction in any medium, provided the original work is properly cited.

\section{PENDAHULUAN}

Perkawinan tidak sekedar peristiwa religius-yuridis semata, lebih dari itu perkawinan bermakna bertemunya dua orang dan keluarganya yang berbeda latar belakang. Perkawinan antar pasangan dengan latar belakang sukubangsa yang berbeda telah menjadi sesuatu yang biasa dalam kondisi Indonesia yang multikultural. Fenomena perkawinan antar sukubangsa ini juga terjadi dan terus mengalami peningkatan dan perluasan di Amerika Serikat (Olson, DeFrain, \& Skogrand, 2011, p. 59). Perkawinan menjadi bukan hanya mempertemukan dua kepribadian yang berbeda, tetapi juga dua budaya sukubangsa yang berbeda.

Setiap sukubangsa di Indonesia memiliki budaya masing-masing, yang berbeda dengan budaya sukubangsa lain. Saat terjadi perkawinan dengan pasangan yang

\footnotetext{
${ }^{1}$ IAIN Pontianak, Indonesia; shidayati.stainptk@gmail.com.
} 
berbeda sukubangsa, maka akan terjadi perjumpaan budaya sukubangsa baik sebelum, pada saat, dan setelah proses perkawinan. Perjumpaan budaya dalam perkawinan tak jarang menimbulkan problem, terutama dalam proses penyesuaian diri pasangan dan keluarga masing-masing. Atwater (1983, p. 198) mengatakan orang yang menikah dengan pasangan yang berbeda latar belakang, baik kelas sosial, agama, ras, dan lainnya, akan menghadapi resiko besar dalam perkawinannya. Lebih khusus lagi Olson, DeFrain \& Skogrand (2011, p. 292) mengatakan pasangan yang berbeda sukubanga (etnis) lebih mungkin untuk bercerai dan memiliki berbagai masalah perkawinan dan keluarga. Meskipun demikian, tidak berarti perkawinan antar sukubangsa tidak bisa mencapai kesuksesan. Perkawinan seperti ini menuntut kemampuan penyesuaian perkawinan yang lebih baik di banding perkawinan antar pasangan satu sukubangsa. Dalam konteks perkawinan antar pasangan berbeda sukubangsa, penyesuaian perkawinan juga bermakna penyesuaian budaya.

Penelitian Matsumoto, LeRoux, Robles, \& Campos (2007) menyimpulkan penyesuaian melibatkan berbagai pengalaman, termasuk kesadaran diri dan harga diri, keadaan mood, dan status kesehatan. Selanjutnya diidentifikasi empat faktor penyesuaian, yaitu: (1) memiliki hubungan yang sukses dengan orang-orang dari budaya lain; (2) perasaan adanya interaksi yang hangat, ramah, hormat, dan koperasi; dan (3) menyelesaikan tugas secara efektif dan efisien; (4) kemampuan mengelola stres psikologis secara efektif. Ada tiga prinsip yang penting diperhatikan terkait dengan hakikat penyesuaian diri yaitu: (1) setiap individu memiliki kualitas penyesuaian diri yang berbeda; (2) penyesuaian diri sebagian besar ditentukan oleh kapasitas internal atau kecenderungan yang telah dicapainya; dan (3) penyesuaian diri juga ditentukan oleh faktor internal dalam hubungannya dengan tuntutan lingkungan individu yang bersangkutan. Schneider (Ali \& Asrori, 2004) menyebutkan tiga unsur yang terlibat dalam penyesuaian diri, yaitu motivasi, sikap terhadap realitas, dan pola dasar penyesuaian diri. Tiga unsur ini akan mewarnai kualitas proses penyesuaian diri individu.

Knox \& Schacht (2010, p. 234) menyamakan kesuksesan perkawinan dengan "satisfaction", "quality", "adjustment", "lack of distress" dan "integration". Hal yang sama juga dinyatakan oleh Sook_Hyun Lee Choi (1987) dengan menyebutkan konsep penyesuaian perkawinan dapat disamakan dengan "sukses", "kebahagiaan", "stabilitas", dan "kepuasan". Choi kemudian mengutip Lively yang berpendapat bahwa penyesuaian perkawinan adalah konsep yang berharga untuk menekankan sifat dinamis dari pernikahan. 
Baginya, penyesuaian perkawinan disebut melanjutkan pengembangan hubungan antara suami dan istri dan kontinuitas antara mereka. Menurut Atwater (1983, p. 198-199) penyesuaian perkawinan merupakan proses pasangan belajar untuk saling menyesuaikan peran, melakukan komunikasi dan menangani konflik, penyesuaian seks, dan menyesuaikan perubahan yang terjadi terkait dengan lamanya perkawinan. Konsep penyesuaian perkawinan yang menyertakan dua individu menuntut kesediaan dua pasangan untuk mengakomodasi berbagai kebutuhan, keinginan, dan harapan pasangan lainnya (Sadarjoen, 2005, p. 22). Penyesuaian perkawinan bermakna pasangan mencapai taraf yang lebih baik dalam hal kenyamanan relasi yang diperoleh melalui saling memberi dan saling mengambil. Dengan demikian penyesuaian diri tidak diartikan suatu kondisi absolut namun lebih kepada suatu proses yang berlanjut.

Menurut Lasswell \& Lasswell (1987), penyesuaian diri adalah pengorganisasian keinginan, kebutuhan, dan harapan-harapan masing-masing, melalui proses yang saling menguntungkan di antara keduanya, yaitu saling memberi dan menerima. Sementara itu, menurut Spanier (dalam Lasswell dan Lasswell, 1987), penyesuaian perkawinan adalah adaptasi pasangan suami istri terhadap perubahan-perubahan yang terjadi pada diri sendiri, pasangannya, dan lingkungan perkawinannya. Dari beberapa definisi di atas dapat disimpulkan penyesuaian perkawinan adalah respon suami atau istri untuk mencapai hubungan harmonis antara kebutuhan diri sendiri, pasangan dan lingkungan. Kemampuan melakukan penyesuaian dalam perkawinan pada setiap individu meliputi tiga aspek, yaitu (1) aspek pikiran; (2) aspek perasaan; dan (3) aspek tindakan.

Sebagai sebuah proses, penyesuaian perkawinan ada yang baik (berhasil) dan ada pula yang tidak baik (gagal). Burgess dan Cotteral dalam Choi (1987) menyebutkan penyesuaian perkawinan yang baik adalah "sebuah perkawinan di mana sikap dan tindakan masing-masing mitra [pasangan] menghasilkan lingkungan yang menguntungkan untuk fungsi kepribadian masing-masing, terutama dalam hubungan utama". Untuk mencapai penyesuaian perkawinan yang baik terdapat delapan faktor yang harus diperhatikan oleh setiap pasangan berbeda sukubangsa, yaitu: (1) Values; (2) Acculturation; (3) Religion; (4) Race; (5) Sex and role sex; (6) Socioeconomic differences; (7) Cultural familiarity; dan (8) Extended-family agreement (Olson, DeFrain, \& Skogrand, 2011, pp. 292-294). Setiap kelompok etnis (sukubangsa) memiliki warisan keunikan tersendiri, nilai-nilai, dan perilaku yang membuatnya menjadi khusus. 
Hal ini penting diperhatikan bagi mereka yang menikah dengan orang dari kelompok [sukubangsa] yang berbeda serta menyadari perbedaan ini untuk selanjutnya menjadikannya sebagai modal daripada sebuah beban.

Dari beberapa penjelasan teoritis di atas, dapat dipahami perkawinan antar pasangan berbeda sukubangsa menuntut kemampuan penyesuaian perkawinan yang baik. Hal ini penting sebagai upaya menghindari resiko rusaknya hubungan perkawinan. Penyesuaian perkawinan bagi pasangan berbeda sukubangsa dengan demikian juga bermakna penyesuaian budaya. Hurlock (1980, p. 290) menyebutkan ada empat masalah pokok yang paling umum dan paling penting bagi kebahagiaan perkawinan yaitu penyesuaian dengan pasangan, penyesuaian seksual, penyesuaian keuangan, dan penyesuaian dengan keluarga dari pihak masing-masing pasangan. Terkait dengan hal ini, meskipun Hurlock membedakan keempat hal tersebut, namun penyesuaian dengan pasangan menjadi yang terpenting, karena tiga hal lainnya terkait dengan pasangan. Oleh karena itu, untuk melihat bagaimana penyesuaian budaya dalam perkawinan pada pasangan berbeda sukubangsa, maka sangat penting untuk menelusuri bagaimana pemikiran, perasaan, dan tindakan salah satu pasangan terhadap pasangannya.

Untuk melihat posisi penelitian ini, peneliti melakukan telaah atas tiga fokus studi yang telah dilakukan oleh para peneliti terdahulu. Pertama, studi yang difokuskan pada perkawinan pasangan yang berbeda budaya terutama yang terkait dengan komunikasi antarbudaya (Charsley, 2005; Sullivan \& Cottone, 2006; Trevino, Wooten, \& Scoot, 2007; Durodoye \& Coker, 2008; Puspowardhani, 2008; Chung \& Yoo, 2013; Pakpahan, 2013; George, Ukpong, \& Imah, 2014). Kedua, studi yang difokuskan pada kepuasan dalam perkawinan, perkawinan yang sukses (Alder, 2010; Ayub \& Iqbal, 2012; Barongo, Okwara, Aloka, \& Masoka, 2015; Barongo, Onderi, Kebari, Okwara, \& Bantu, 2014; Mihalcea, Iliescu, \& Dinca, 2013; Ojukwu, Woko, \& Onuoha, 2016; Zainah, Nasir, Hashim, \& Yusof, 2012; Al-Darmaki, et al., 2014). Ketiga, studi yang secara khusus menyoroti penyesuaian dalam perkawinan (Arshad, Mohsin, \& Mahmoud, 2014; Basharpoor \& Sheykholeslami, 2015; Choi, 1987; Chung \& Yoo, 2013; Muraru \& Turliuc, 2013; Quinn \& Odell, 1998; Trevino, Wooten, \& Scoot, 2007; Charsley, 2005).

Berbagai penelitian yang mencakup tiga fokus isu di atas menjadi bahan bacaan penting dalam pelaksanaan penelitian ini. Selain untuk memperkaya bacaan, juga untuk menentukan posisi penelitian yang dilakukan. Seperti telah 
disebutkan sebelumnya, penelitian ini berupaya mengungkap penyesuaian budaya dalam perkawinan, yaitu respon suami atau istri untuk mencapai hubungan harmonis antara kebutuhan diri sendiri dan pasangannya yang berbeda sukubangsa. Secara spesifik penelitian ini berupaya mendeskripsikan kemampuan individu untuk menyelaraskan aspek pikiran, perasaan, dan tindakan suami atau istri terhadap pasangannya yang berbeda sukubangsa dalam berbagai sisi kehidupan keluarga.

\section{METODE}

Penelitian bermaksud menjelaskan fenomena penyesuaian budaya dalam perkawinan pada pasangan berbeda sukubangsa. Oleh karena itu penelitian ini berupaya mengungkapkan dan menganalisis aspek pikiran, perasaan, dan tindakan dalam proses penyesuaian budaya dalam perkawinan. Untuk maksud tersebut penelitian ini menggunakan metode deskriptif dengan pendekatan kuantitatif. Sampel penelitian dilakukan menggunakan simple random sampling. Responden dalam penelitian ini sebanyak 50 orang, terdiri dari 15 orang laki-laki dan 35 orang perempuan yang menikah dengan pasangan yang berbeda suku. Dari aspek kesukubangsaan, responden penelitian ini berasal dari sukubangsa Jawa, Melayu, Sunda, Banjar, Bugis, Madura, dan Manado, Batak, Betawi, Dayak, dan Bali. Dari aspek tingkat pendidikan, variasi tingkat pendidikan responden mulai dari jenjang SMP sampai jenjang Starata 2. Dari aspek usia pernikahan responden diklasifikasikan usia pernikahan 0-6 tahun, 712 tahun, 13-18 tahun, 19-24 tahun, 25-30 tahun, dan 31-35 tahun. Data dikumpulkan dengan menggunakan kuesioner yang dibuat berdasarkan skala ordinal. Analisis data menggunakan korelasi Pearson Product Moment.

Penelitian ini mengambil lokasi di Kota Pontianak, Provinsi Kalimantan Barat. Kota Pontianak merupakan Ibukota Provinsi Kalimantan Barat. Kota yang dijuluki kota $\mathrm{K}$ vhatulistiwa ini terdiri dari enam kecamatan yaitu: Pontianak Barat, Pontianak Kota, Pontianak Selatan, Pontianak Tenggara, Pontianak Timur, dan Pontianak Utara. Secara keseluruhan luas kota Pontianak 107,82 $\mathrm{km}^{2}$. Dipilihnya kota Pontianak sebagai lokasi penelitian karena dari segi kesukubangsaan, penduduk kota Pontianak sangat beragam atau multibudaya. Data statistik memang tidak ditemukan, namun dalam kehidupan sehari-hari terdapat tiga sukubangsa yang dominan, yaitu Melayu, Tionghoa dan Dayak. Sukubangsa lain yang cukup menonjol adalah Bugis, Madura, Jawa, Banjar, Sunda, Batak, Padang, dan sebagainya. Pluralitas sukubangsa itu kemudian 
membuka ruang dan menjadi hal yang lumrah terjadi perkawinan campur antar sukubangsa yang ada. Hal lain yang juga menjadi bahan pertimbangan menjadikan Kota Pontianak sebagai lokasi penelitian adalah jumlah angka perceraiannya yang terhitung tinggi. Data dari Pengadilan Agama Pontianak menunjukkan jumlah kasus perceraian terus meningkat dari tahun ke tahun. Tahun 2010 sebanyak 839 kasus, tahun 2011 sebanyak 942 kasus, tahun 2012 sebanyak 1147 kasus, dan tahun 2013 sebanyak 1154 kasus (Hidayati, 2014).

\section{HASIL DAN PEMBAHASAN}

Studi ini bertujuan untuk menghasilkan deskripsi tentang profil penyesuaian budaya dalam perkawinan. Untuk menggambarkan kemampuan penyesuaian budaya dalam perkawinan digunakan tiga aspek, yaitu pikiran, perasaan, dan tindakan. Melalui kuesioner, diukur kemampuan individu untuk menyelaraskan pikiran, perasaan, dan tindakan dalam konteks keluarga yang berbeda sukubangsa. Pada aspek pikiran, ada tiga indikator yang digunakan, yaitu pengetahuan, pemahaman, dan pertimbangan. Aspek perasaan menggunakan tiga indikator, yaitu penghargaan, penerimaan, dan perhatian. Selanjutnya aspek tindakan menggunakan tiga indikator, yaitu peran, perlakuan, dan perbuatan. Hasil analisis terhadap ketiga aspek tersebut digambarkan dalam Gambar 1.

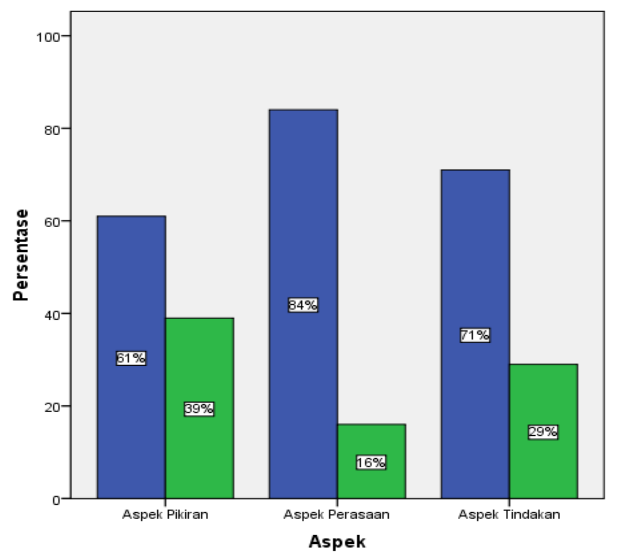

早raak

Gambar 1. Grafik Hasil Analisis pada Setiap Aspek

Gambar 1 menunjukkan bahwa secara umum kemampuan penyesuaian budaya dalam perkawinan pada aspek pikiran yaitu 61 persen menjawab iya dan 39 persen menjawab tidak. Kemampuan individu untuk menyelaraskan perasaan 84 persen menjawan iya dan 16 persen menjawab tidak. Kemampuan individu menyesuaikan budaya dalam perkawinan pada aspek tindakan 71 persen 
menjawab "Ya" dan 29 persen menjawab "Tidak". Berikut hasil analisis untuk setiap aspek dan indikator.

Aspek Pikiran: Kemampuan individu untuk menyelaraskan pikiran pada indikator pengetahuan menjelaskan bahwa 61,85 persen menjawab iya dan 38,15 persen menjawab tidak. Kemampuan individu untuk menyelaraskan pikiran pada indikator pemahaman menjelaskan bahwa 88,5 persen menjawab iya dan 11,5 persen menjawab tidak. Sementara itu kemampuan individu untuk menyelaraskan pikiran pada indikator pertimbangan menjelaskan bahwa 41,7 persen menjawab iya dan 58,3 persen menjawab tidak.

Data ini menunjukkan 61,85 persen responden mengetahui bahwa ia berbeda suku dan hoby dengan pasangannya, mengetahui kelebihan dan kekurangan pasangan serta mengenal keluarga pasangan. Selanjutnya ada sebanyak 88,5 persen responden sudah mengenal pasangannya, berusaha mempelajari bahasa ibu pasangan, berkomitmen untuk menjaga keutuhan pernikahan, dan memahami perbedaan budaya dengan pasangan tidak menjadi masalah dalam perkawinan. Selanjutnya sebanyak 41,7 persen responden yang menyatakan menikah karena dijodohkan, mempertimbangkan usia, tingkat pendidikan, sukubangsa, agama, dan hoby pasangan saat akan menikah.

Aspek Perasaan: Kemampuan individu untuk menyelaraskan perasaan pada indikator penghargaan menjelaskan bahwa 94,0 persen menjawab iya dan 6,0 persen menjawab tidak. Kemampuan individu untuk menyelaraskan perasan pada indikator penerimaan menjelaskan bahwa 86,8 persen menjawab iya dan 13,2 persen menjawab tidak. Kemampuan individu untuk menyelaraskan perasaan pada indikator perhatian menjelaskan bahwa 67,0 persen menjawab iya dan 33,0 persen menjawab tidak. Data ini menunjukkan dari aspek perasaan responden memiliki kemampuan penyesuaian budaya paling tinggi pada indikator penghargaan, disusul penerimaan, dan perhatian. Hampir seluruh responden atau 94 persen menyatakan menghargai perbedaan dan menunjukkan rasa cinta dengan memuji pasangannya. Sebanyak 86,8 persen menyatakan bahagia, saling mencintai, saling mempercayai, dan menyatakan kebahagiaannya terletak pada kebahagiaan pasangannya. Dari sisi perhatian, sebanyak 67 persen responden menyatakan peduli dengan pasangan dan termasuk dengan tradisi pasangan.

Aspek Tindakan: Kemampuan individu untuk menyelaraskan tindakan pada indikator peran menjelaskan bahwa 66,0 persen menjawab iya dan 34,0 persen menjawab tidak. Kemampuan individu untuk menyelaraskan tindakan pada 
indikator peran menjelaskan bahwa 36,3 persen menjawab iya dan 64,7 persen menjawab tidak. Kemampuan individu untuk menyelaraskan tindakan pada indikator perbuatan menjelaskan bahwa 95,6 persen menjawab iya dan 4,4 persen menjawab tidak. Data ini menunjukkan dari aspek tindakan, 66 persen responden bertugas mengatur keuangan pasangan, sebagai pencari nafkah dan menjadikan tanggung jawab bersama pasangan dalam tugas-tugas rumah tangga. Hanya sebagian kecil atau 36,3 persen responden selalu melibatkan keluarga besar dalam menghadapi masalah dengan pasnagan, keluarga pasangan sering mencampuri urusan rumah tangganya, dan mengingatkan pasangan jika berlaku kurang sopan dengan keluarganya. Selanjutnya hampir semua atau 95,6 persen responden berinisiatif menyelesaikan masalah dalam pernikahan, mengkomunikasikan perbedaan yang ada, berusaha membangun kecocokan, pada waktu tertentu mengajak pasangan rekreasi dan selalu menjaga hubungan baik dengan mertua.

Berdasarkan paparan hasil analisis pada aspek pikiran, perasaan, dan tindakan di atas terlihat bahwa pasangan yang melakukan perkawinan dengan suami atau istri yang berbeda sukubangsa mampu melakukan penyesuaian diri dengan baik. Individu yang menjadi responden dalam riset ini mampu menunjukkan pikiran, perasaan, dan tindakan yang diperlukan dalam menyesuaikan diri dengan pasangan yang berbeda budaya. Sebagaimana dinyatakan oleh Burges dan Cotteral (dalam Choi, 1987) bahwa penyesuaian perkawinan dikatakan baik jika sikap dan tindakan masing-masing pasangan menghasilkan lingkungan yang menguntungkan untuk fungsi kepribadian masing-masing, terutama dalam hubungan utama.

Hasil penelitian tentang variabel penyesuaian yang baik dalam kehidupan perkawinan di antaranya yaitu relasi saling mencintai, pasangan mengelola kehidupan perkawinan dengan cara yang efektif, faktor-faktor yang terkait dengan mencintai, saling menghormati, kompetensi dalam peran perilaku, penolong, dan perilaku berbagi dalam segala hal di antara pasangan (Sadarjoen, 2005). Olson, DeFrain, \& Skogrand (2011) menyatakan bahwa untuk menyesuaikan diri dengan baik dalam kehidupan perkawinan terdapat delapan faktor yang perlu diperhatikan oleh pasangan yang berbeda budaya yaitu: (1) values; (2) acculturation; (3) religion; (4) race; (5) sex and role sex; (6) socioeconomic differences; (7) cultural familiarity; dan (8) extended-family agreement.

Selain mengukur kemampuan penyesuaian budaya berdasarkan tiga aspek yang telah disebutkan di atas, peneliti juga melihat korelasi karakteristik individu 
terhadap penyesuaian budaya dalam perkawinan. Karakteristik responden yang dilihat korelasinya dengan penyesuaian budaya dalam perkawinan adalah aspek jenis kelamin, kesukubangsaan, pendidikan, dan usia perkawinan.

Jenis kelamin: Korelasi jenis kelamin dengan penyesuaian budaya dalam perkawinan menjelaskan bahwa 69,9 persen pada wanita dan 30,1 persen pada laki-laki. Ini bermakna perempuan lebih mampu melakukan penyesuaian budaya di banding laki-laki. Penelitian Quinn dan Odell (1998), serta penelitian Muraru dan Turliuc (2013) menunjukkan tidak ada perbedaan tingkat penyesuaian diri dalam perkawinan antara laki-laki dan perempuan. Berbeda dengan temuan Quinn \& Odell, penelitian ini menunjukkan bahwa perempuan memiliki tingkat penyesuaian budaya dalam perkawinan yang lebih tinggi dibandingkan dengan laki-laki. Jika ditelusuri lebih jauh, hal ini disebabkan perempuan cenderung menghargai aspek-aspek hubungan dari perkawinan lebih tinggi daripada laki-laki. Menurut salah satu studi, tiga teratas kebahagiaan untuk perempuan menikah adalah cinta, perkawinan dan kebahagiaan dari pasangan mereka, sementara peringkat yang berhubungan bagi laki-laki adalah pertumbuhan pribadi, cinta dan perkawinan (Atwater, 1983, p. 197).

Kesukubangsaan: Korelasi kesukubangsaan dengan penyesuaian budaya dalam perkawinan menjelaskan bahwa 37,4 persen pada sukubangsa Jawa, 32,5 persen pada sukubangsa Melayu, 6,2 persen pada sukubangsa Sunda, 6,1 persen pada sukubangsa Banjar, 4,3 persen pada Sukubangsa Bugis, 3,7 persen pada sukubangsa Madura, 2,1 persen pada sukubangsa Manado, 2,0 persen pada sukubangsa Batak, 2,0 persen pada sukubangsa Betawi, 1,8 pada sukubangsa Dayak dan 1,9 persen pada sukubangsa Bali.

Koentjaraningrat (1997) menyebutkan ada lima orientasi nilai budaya pada tiap suku bangsa, termasuk sukubangsa Jawa. Lima orientasi nilai budaya itu adalah hakikat hidup, hakikat kerja, hubungan antara manusia dengan alam, persepsi mengenai waktu, dan hubungan antara manusia dan sesamanya. Dalam hal orientasi nilai hubungan antara manusia dengan sesamanya, tingkah laku dan adat sopan santun orang Jawa terhadap sesamanya sangat berorientasi secara kolateral. Bahwa mereka hidup tidak sendiri di dunia, maka mereka hidup saling tolong menolong, saling memberikan bantuan. Mereka mengembangkan sikap tenggang rasa (tepa salira), dan berlaku conform dengan sesamanya. Mereka juga mengintensifkan solidaritas antara para anggota suatu kelompok kerabat. 
Pendidikan: Korelasi pendidikan terakhir dengan penyesuain budaya dalam perkawinan menunjukkan 53,7 persen pada pendidikan S1, 20,2 persen pada pendidikan S2, 9,9 persen pada pendidikan SMA, 8,0 persen pada pendidikan D3, 4,2 persen pada pendidikan SMP, 2,1 persen pada pendidikan D2 dan 2,1 persen pada pendidikan D1. Data ini menunjukkan ada linearitas atau korelasi positif antara tingkat pendidikan dan kemampuan penyesuaian budaya. Dengan kata lain semakin tinggi tingkat pendidikan seseorang, maka semakin baik pula kemampuan penyesuaian budaya mereka dalam perkawinan. Penelitian di Kisii County-Kenya oleh Barongo, Okwara, Aloka, \& Masoka (2015) dan penelitian Alder (2010) menunjukkan tidak ada hubungan statistik yang signifikan antara tingkat pendidikan dan kepuasan pernikahan. Namun beberapa penelitian lain menunjukkan kesamaan dengan hasil penelitian ini. Penelitian yang dilakukan di Pakistan (Ayub \& Iqbal, 2012) menunjukkan salah satu faktor yang berkontribusi terhadap kepuasan perkawinan adalah tingkat pendidikan pasangan. Penelitian di Romania (Mihalcea, Iliescu, \& Dinca, 2013) menunjukkan para sarjana memiliki kemampuan yang tinggi dalam memahami masalah-masalah keuangan, agama, dan pemanfaatan waktu luang dan ini menjadi faktor khusus dalam proses penyesuaian dengan pasangan.

Pendidikan pun turut mempengaruhi pola penyesuaian perkawinan pada pasangan suami istri. Penelitian Dyer (1983) menunjukkan semakin tinggi tingkat pendidikan pasangan suami istri, maka mempunyai kemungkinan lebih besar untuk melakukan penyesuaian perkawinan dan sedikit terjadinya perceraian. Strong, DeVault, \& Cohen (2011, p. 283) menyatakan bahwa tingkat pendidikan turut mempengaruhi pernyesuaian perkawinan dan juga perceraian. Pendidikan dapat memberi kita sumber daya tambahan, layaknya pendapatan, wawasan, atau status, yang berkontribusi terhadap peran perkawinan. Penelitian Ojukwu, Woko, \& Onuoha (2016) di Imo-Nigeria, menunjukkan ada hubungan positif antara tinggi atau rendahnya tingkat pencapaian pendidikan orang yang sudah menikah dengan stabilitas perkawinan. Artinya, semakin tinggi pendidikan orang yang sudah menikah maka semakin stabil perkawinannya.

Usia perkawinan: Korelasi usia perkawinan dengan penyesuain budaya dalam perkawinan menjelaskan bahwa 32,3 persen pada usia perkawinan 7-12 tahun, 19,9 persen pada usia perkawinan 1-6 tahun, 16,3 persen pada usia perkawinan 19-24 tahun, 13,6 persen pada usia perkawinan 25-30 tahun, 10,3 persen pada usia perkawinan 31-36 tahun, dan 7,6 persen pada usia perkawinan 13-18 tahun. Data ini menunjukkan penyesuaian budaya pada usia perkawinan 1 s.d. 6 tahun cukup baik, dan semakin baik ada saat usia perkawinan antara 7 sampai 12 
tahun. Masa penyesuaian budaya yang buruk terjadi pada rentang usia perkawinan 13 s.d. 18 tahun. Selanjutnya penyesuaian budaya mulai stabil pada usia perkawinan setelah melewaati 18 tahun dan seterusnya. Dengan demikian yang perlu diwaspadai adalah pada usia perkawinan 13-18 tahun di mana pada rentang waktu ini kemampuan penyesuain budaya pasangan suami istri rendah. Penelitian di Malaysia yang dilakukan oleh Zainah, Nasir, Hashim, \& Yusof (2012) menemukan semakin lama durasi pernikahan, semakin puas individu dengan pernikahannya. Seseorang yang puas dengan pernikahannya merupakan indikasi bahwa ia juga dalam hubungan yang baik dengan pasangannya (Nasir \& Amin, 2010). Pasangan yang usia pernikahannya di atas sepuluh tahun mungkin telah melewati tahap penyesuaian dan adaptasi dan akan kurang mengalami masalah psikologis dan tekanan. Selain itu, seperti yang disarankan oleh Olson, Russel, \& Sprenkle (1983) dalam Model Circumplex, kohesi tinggi dalam pernikahan dapat membantu pasangan melintasi periode sulit penyesuaian, dan fleksibilitas yang seimbang dapat membuat mereka senang dan puas dengan pernikahan mereka.

Atwater (1983, pp. 204-205) menulis bahwa salah satu perubahan yang paling konsisten adalah berkurangnya kebahagiaan perkawinan, terutama setelah beberapa tahun pertama perkawinan. Roger Gould (1978) menemukan bahwa setelah beberapa tahun pertama, pasangan-pasangan biasanya kurang yakin bahwa perkawinan mereka adalah hal yang baik. Alasannya biasanya adalah karena transisi dari cinta romantis ke realitas sehari-hari ketika hidup bersama. Ketika kedua pasangan menjadi lebih sadar akan kebutuhan mereka untuk saling menyesuaikan diri daripada saling menginginkan, maka umumnya mereka menjadi kurang puas terhadap perkawinan mereka. Berbagai perubahan dalam kepuasan perkawinan juga dipengaruhi oleh hal-hal seperti hadirnya anak-anak, jumlah anak dan usia mereka, dan lamanya perkawinan. Umumnya ada tingkat tinggi kebahagiaan perkawinan dalam dua tahun pertama, diikuti penurunan tajam antara tahun kedua dan kedelapan, dengan ikatan kembali yang kuat pada tahun kesembilan dan kesepuluh dari perkawinan.

\section{SIMPULAN}

Berdasarkan data yang telah di analisis di atas, disimpulkan bahwa penyesuaian budaya dalam perkawinan pada seluruh responden menunjukkan telah mencapai well adjustment. Kesimpulan ini didukung oleh data bahwa dari ketiga aspek yang diukur diperoleh angka tingkat penyesuaian responden 
sebagai berikut: aspek pikiran 61 persen, perasaan 84 persen, dan tindakan 71 persen. Data juga menunjukkan bahwa dalam menentukan pasangan saat menikah, responden tidak terlalu mempertimbangkan berbagai latar belakang pasangannya. Ini bermakna mereka tidak mempermasalahkan adanya perbedaan budaya dengan pasangan. Mereka memiliki komitmen yang cukup tinggi dalam perkawinan, sehingga aspek perasaan cukup tinggi yang bermakna kepuasan dan keharmonisan hubungan dengan pasangan.

Penyesuaian budaya dalam perkawinan responden berkorelasi positif terhadap tingkat pendidikan. Semakin tinggi pendidikan seseorang maka kemampuan penyesuaian budayanya semakin baik. Dari aspek gender, perempuan memiliki kemampuan lebih baik daripada laki-laki dalam penyesuaian budaya dalam perkawinan. Dari aspek kesukubangsaan, sukubangsa Jawa menunjukkan kemampuan lebih baik dalam penyesuaian budaya daripada sukubanga yang lain. Sedangkan dari aspek lamanya usia perkawinan, sejak awal perkawinan hingga menginjak tahun ke-12, proses penyesuaian perkawinan cukup baik. Hanya pada rentang usia perkawinan tahun ke-13 s.d. ke-18 mengalami penyesuaian perkawinan yang buruk. Baru setelah tahun ke-19 dan seterusnya proses penyesuaian mengalami peningkatan lebih baik dan cenderung stabil.

Hasil kajian literatur dan hasil penelitian ini menunjukkan studi terkait penyesuaian budaya dalam perkawinan khususnya di Indonesia masih minim. Padahal tren perkawinan antar sukubangsa yang berbeda terus meningkat seiring perkembangan iptek dan sosial budaya. Studi di bidang ini sangat penting untuk memperkaya ilmu bimbingan dan konseling khususnya bimbingan dan konseling keluarga yang berbasis budaya Indonesia. Implikasi penting dari hasil penelitian adalah salah satu prediktor kesuksesan perkawinan adalah penyesuaian budaya antar pasangan suami istri. Hal lain yang juga layak dipertimbangkan untuk memperkaya ilmu bimbingan dan konseling keluarga adalah temuan bahwa responden saat ini cenderung tidak lagi memikirkan latar belakang pasangannya saat akan menikah. Hal ini berbeda dengan beberapa dekade yang lalu, di mana pada sebagian masyarakat masih menganggap tabu menikah dengan pasangan yang berbeda sukubangsa. Hal ini merupakan hal yang positif dalam konteks penyesuaian budaya; yang bermakna mereka telah siap melakukan proses penyesuaian budaya.

Penelitian ini juga dapat dijadikan bahan pertimbangan bagi para konselor yang memberikan layanan bimbingan dan konseling pranikah, perkawinan dan keluarga. Konselor pranikah dapat memberikan bimbingan kepada klien bahwa perkawinan tidak sekedar penyatuan dua individu, tetapi juga bertemunya dua 
budaya. Pasangan yang berbeda sukubangsa harus memiliki kesiapan individu dalam proses penyesuaian perkawinan, khususnya menghadapi budaya yang berbeda dari pasangannya. Konselor perkawinan dan keluarga juga harus memiliki pemahaman bahwa salah satu konflik perkawinan atau keluarga dapat bersumber dari perbedaan budaya suami dan istri. Resolusi konflik yang ditawarkan juga dapat mengacu pada peningkatan kemampuan melakukan penyesuaian budaya pada diri suami-istri.

\section{REFERENSI}

Ahmad, A. L., Zamri, N. Z., Salman, A., Mohamed, E. M., \& Hashim, H. (2014). Isu-isu dan masalah adaptasi antarbudaya dalam kalangan pelajar Malaysia di United Kingdom dan Australia. e-BANGI, 9(2), 162-171.

Al-Darmaki, F. R., Hassane, S. H., Ahammed, S., Abdullah, A. S., Yaaqeib, S. I., \& Dodeen, H. (2014). Marital satisfaction in the United Arab Emirates: Development and validation of a culturally relevant scale. Journal of Family Issues, 1-27. doi:10.1177/0192513X14547418

Alder, E. S. (2010). Age, Education Level, and Length of Courtship in Relation to Marital Satisfaction. Hillsboro: Pacific University. Diambil kembali dari http://commons.pacificu.edu/spp/145

Ali, M., \& Asrori, M. (2004). Psikologi remaja perkembangan peserta didik. Bandung: Bumi Aksara.

Arshad, M., Mohsin, M. N., \& Mahmoud, K. (2014). Marital Adjustment And Life Satisfaction Among Early And Late Marriage. Journal of Education and Practice, 5(17), 80-90.

Atwater, E. (1983). Psychology of adjustment (2nd ed.). New Jersey: Prentice Hall.

Ayub, N., \& Iqbal, S. (2012). The Factors Predicting Marital Satisfaction: A Gender Difference in Pakistan. The International Journal of Interdisciplinary Social Sciences, 6(7), 63-73. Diambil kembali dari https://www.researchgate.net/publication/255712960

Barongo, S., Okwara, M., Aloka, P., \& Masoka, N. O. (2015). Association of Levels of Education and Marital Experience on Marital Satisfaction among Selected Marriages in Kisii Township Kisii County. Research on Humanities and Social Sciences, 5(8), 27-32.

Barongo, S., Onderi, P., Kebari, Z., Okwara, M., \& Bantu, E. (2014). Correlates between Levels of Education in Relation to Marital Satisfaction in KISII Township of KISII County, Kenya. International Journal of Innovation and Applied Studies, 9(1), 387-392. Diambil kembali dari http://www.ijias.issr-journals.org/ 
Basharpoor, S., \& Sheykholeslami, A. (2015). The Relation of Marital Adjustment and Family Functions With Quality of Life in Women. Europe's Journal of Psychology, 11(3), 432-441. doi:10.5964/ejop.v11i3.859

BKKBN. (2013). Badan Koordinasi Keluarga Berencana Nasional. Dipetik Mei 24, 2016, dari BKKBN: http://bkkbn.go.id.

Black, J. S., \& Stephens, G. K. (1989). The influence of the spouse on American expatriate adjustment and intent to stay in Pacific Rim Overseas assignments. Journal of Manajement, 15(4), 529-544. doi:10.1177/014920638901500403

Charsley, K. (2005). Vulnerable brides and transnational ghar damads: Gender, risk and adjumstment among Pakistani marriage migrants to Britain. Indian Journal of Gender Studies, 12, 381-406. doi:10.1177/097152150501200210

Choi, S. H. L. (1987). The marital adjustment process of Korean working-class couples. Iowa: Iowa State University.

Chung, G. H., \& Yoo, J. P. (2013). Using the multicultural family support centers and adjustment among interethnic and interracial families in South Korea. Family Relations, 62(1), 241-253. doi:10.1111/j.17413729.2012.00754.x

Durodoye, B. A., \& Coker, A. D. (2008). Crossing cultures in marriage: Implications for counseling African American/African couple. Internaional Journal Advancement of Counseling, 30, 25-37. doi:10.1007/s10447-007-9042-9

Ember, C. R., \& Ember, M. (2013). Konsep Kebudayaan. In T. Ihromi (Penyunt.), Pokok-pokok antropologi budaya (pp. 13-31). Jakarta: Yayasan Pustaka Obor Indonesia.

Fahmy, M. (1977). Kesehatan jiwa dalam keluarga sekolah dan masyarakat. (Z. Daradjat, Penerj.) Jakarta: Bulan Bintang.

George, I. N., Ukpong, D. E., \& Imah, E. E. (2014). Cultural diversity of marriage sustainability in Nigeria: Strenghts and challanges. Sosiology and Anthropology, 2(1), 7-14. doi:10.13189/sa.2014.020102

Harris, P., \& Moran, R. T. (2005). Memahami perbedaan-perbedaan budaya. In D. Mulyana, \& J. Rakhmat (Penyunt.), Komunikasi antarbudaya: Panduan berkomunikasi dengan orang-orang berbeda budaya (pp. 5471). Bandung: Remaja Rosdakarya.

Hidayati, S. (2007). Program konseling komprehensif untuk meningkatkan kemampuan penyesuaian diri muallaf (Studi kasus pada forum komunikasi pembinaan muallaf Tionghoa di kota Pontianak Kalimantan Barat). Universitas Pendidikan Indonesia. Bandung: Sekolah Pascasarjana Universitas Pendidikan Indonesia. 
Hidayati, S. (2014). Problematika Pelaksanaan Penasihatan Perkawinan di Kantor Urusan Agama Kecamatan Pontianak Timur Kota Pontianak. IAIN Pontianak. Pontianak: LP2M IAIN Pontianak.

Hurlock, E. B. (1980). Psikologi Perkembangan Suatu Pendekatan Sepanjang Rentang Kehidupan (ke-5 ed.). (I. Soedjarwo, Penerj.) Jakarta: Erlangga.

Knox, D., \& Schacht, C. (2010). Choices in relationships: An introduction to marriage and the family (10th ed.). Belmont: Wadsworth.

Koentjaraningrat. (1997). Kebudayaan, mentalitas dan pembangunan. Jakarta: Gramedia Pustaka Utama.

Lasswell, \& Laswell. (1987). Marriage and the family (2nd ed.). California: Wadworth Publishing.

Lysgaard, S. (1955). Adjustment in a foreign society: Norwegian Fulbright grantees visiting the United States. International Science Bulletin. 7: 45$51,7,45-51$.

Matsumoto, D. (2004). Pengantar psikologi lintas budaya. (A. Aditomo, Penerj.) Yogyakarta: Pustaka Pelajar.

Matsumoto, D., LeRoux, J. A., Robles, Y., \& Campos, G. (2007). The intercultural adjustment potential scale (ICAPS) predicts adjustment above and beyond personality and general intelegence. International Journal of Intercultural Ralations, 31, 747-759. doi:10.1016/j.ijintrel.2007.08.002

Mihalcea, A., Iliescu, D., \& Dinca, M. (2013). The Influence of the Educational Level on Couple Relationships. Procedia Social and Behavioral Sciences, 78, 41-45. doi:10.1016/j.sbspro.2013.04.247

Muraru, A. A., \& Turliuc, M. N. (2013). Predictors of Marital Adjustment: Are There Any Differences Between Women and Men? Europe's Journal of Psychology, 9(3), 427-442. doi:10.5964/ejop.v9i3.524

Nasir, R., \& Amin, S. M. (2010). Job satisfaction, job performance and marital satisfaction among dual-worker Malay couple. International Journal of Interdisciplinary Social Science, 5(3), 299-306.

Oberg, K. (2006). Cultural shock: Adjustment to new cultural environments. Curare, 29(2+3), 142-146.

Ojukwu, M. O., Woko, S., \& Onuoha, R. (2016). Impact of Educational Attainment on Marital Stability among Married Pesons in Imo State, Nigeria. International Journal of Education \& Literacy Studies, 4(3), 8896. doi:10.7575/aiac.ijels.v.4n.3p.88

Olson, D. H., DeFrain, J., \& Skogrand, L. (2011). Marriage and families: Intimacy, diversity, and strengths (7th ed.). New York: Mc Graw Hill. 
Olson, D. H., Russel, C. S., \& Sprenkle, D. H. (1983). Circumplex model of marital and family systems: Vi. Theoretical update. Family Process, 22(1), 63-83. doi:10.1111/j.1545-5300.1983.00069.x

Pakpahan, F. B. (2013). Fungsi komunikasi antar budaya dalam prosesi pernikahan adat Batak di kota Samarinda. E-Journal Ilmu Komunikasi, $1(3), 234-248$.

Poerwanto, H. (2005). Kebudayaan dan Lingkungan dalam Perspektif Antropologi. Yogyakarta: Pustaka Pelajar.

Porter, R. E., \& Samovar, L. A. (2005). Suatu pendekatan terhadap komunikasi antarbudaya. In D. Mulyana, \& J. Rachmat (Penyunt.), Komunikasi antar budaya: Panduan berkomunikasi dengan orang-orang berbeda budaya (pp. 11-35). Bandung: Remaja Rosdakarya.

Puspowardhani, R. (2008). Komunikasi antar budaya dalam keluarga kawin campur Jawa-Cina di Surakarta. Surakarta: Pogram Pascasarjana Universitas Sebelas Maret.

Quinn, W. H., \& Odell, M. (1998). Predictor of marital adjustment during the first two years. Marriage \& Family Review, 23(1/2), 113-130.

Sadarjoen, S. S. (2005). Konflik marital pemahaman konseptual, aktual dan alternatif solusinya. Bandung: Refika Aditama.

Strong, B., DeVault, C., \& Cohen, T. F. (2011). The marriage and family experience: Intimate relationship in a changing society (11th ed.). Belmont: Wadsworth.

Sullivan, C., \& Cottone, R. R. (2006). Culturally based couple therapy and intercultural relationships: A review of literature. The Family Journal: Counseling and Therapy for Couples and Families, 14(3), 221-225. doi:10.1177/1066480706287278

Trevino, Y. A., Wooten, H. R., \& Scoot, R. E. (2007). A correlational study between depression and marital adjustment in Hispanic couples. The Family Journal: Counseling and Therapy for Couples and Families, 15(1), 46-52. doi:10.1177/1066480706294033

Zainah, A. Z., Nasir, R., Hashim, R. S., \& Yusof, N. M. (2012). Effects of Demographic Variables on Marital Satisfaction. Asian Social Science, 8(9), 46-49. doi:10.5539/ass.v8n9p46 